\author{
PIOTR KOSMATY \\ Krajowa Szkoła Sądownictwa i Prokuratury \\ Prokuratura Regionalna w Krakowie
}

\title{
Odpowiedzialność redaktora za przestępstwo prasowe (art. 49a)
}

\begin{abstract}
The main aim of the article is to discuss the issue of the liability of an editor for a press offence, according to Article 49a of the press law. The analysis begins with a historical overview which shows the evolution of liability for offences committed in print by press outlets. To this end, the author introduces the concepts of the right of anonymity or the responsible editor. These two institutions, characteristic of the interwar period, performed two extremely different functions. The former allowed to conceal the identity of the author of the printed material, while the latter was instituted in order to ensure that the victims were sufficiently protected.

The analysis of the current provisions of the press law showed that the legislator introduced two separate legal definitions: that of an editor and that of an editor in chief. The following part of the article discusses those two categories in more detail, paying particular attention to the decoding of their definitions as introduced in the press law from a practical standpoint. Moreover, it has been emphasized that each editor in chief is also an editor, but not vice versa, since some regulations are addressed specifically to the editor in chief.

Bearing in mind that assigning liability for a press offence is dependent on determining the moment from which a person can be considered an editor in chief, the author discusses the registration system for journals and periodicals. As a result, the author determines three distinct periods of time which determine the possibility of considering a particular person as an editor in chief.

The last part of the article is devoted to the rules and circumstances of prosecution of the editor for publishing a press article. The author points to the differences which stem from assuming a different subject party of the offence. In the cases of assuming negligence, it results in liability under Article 49a of the press law, whereas in the cases of assuming intentionality results in liability for an intentional offence of another type committed in complicity.
\end{abstract}

Key words: press law, press offence, right of anonymity, editor in chief, journalist 


\section{Wprowadzenie - materiał prasowy, przestępstwo prasowe}

Odpowiedzialność karną za przestępstwo popełnione w treści materiału prasowego ponosi przede wszystkim jego autor. Autorem materiału prasowego może być w zasadzie każdy, od dziennikarza poprzez polityka udzielającego wywiadu, ekonomistę piszącego specjalistyczny tekst aż po autora listu do redakcji. Może nim też być autor fotografii, rysunku, karykatury czy nagrania fonicznego lub wizualnego. Autor materiału prasowego ponosi odpowiedzialność karną na zasadach ogólnych, co oznacza, że może być sprawcą, współsprawcą, pomocnikiem czy podżegaczem przestępstwa prasowego.

Zgodnie z art. 7 ust. 2 pkt 4 ustawy Prawo prasowe ${ }^{1}$ materiałem prasowym jest każdy opublikowany lub przekazany do opublikowania $\mathrm{w}$ prasie tekst albo obraz o charakterze informacyjnym, publicystycznym, dokumentalnym lub innym, niezależnie od środków przekazu, rodzaju, formy, przeznaczenia czy autorstwa. Zaprezentowana przez ustawodawcę definicja materiału prasowego sformułowana została bardzo ogólnie, zakreślając szerokie granice kwalifikacji tekstu jako materiału prasowego. Definicja ta ponadto nie posiada katalogu desygnatów, które uznane byłyby za materiały prasowe. Otwarta formuła charakteru tekstu oraz środka wyrazu (niezależnie od rodzaju i formy) pozwala zakwalifikować jako materiał prasowy m.in.: artykuł informacyjny, felieton, fotografię, powieść odcinkową, notkę informacyjną, wywiad, reportaż, esej, wiersz, list do redakcji, reklamę, ogłoszenie, komunikat urzędowy, film, rysunek, wykres, tekst sprostowania, plakat stanowiący dodatek do periodyku itp. W doktrynie sporne pozostaje, czy wpisy, posty i komentarze na internetowym forum dyskusyjnym można zakwalifikować jako materiał prasowy. Do tego katalogu należy jednakże bezspornie zaliczyć każdy tekst lub obraz nieopublikowany, ale przeznaczony do publikacji. Potwierdził to Sąd Apelacyjny w Gdańsku w wyroku z dnia 2 czerwca 2010 r. ${ }^{2}$, stwierdzając, że materiałem prasowym jest materiał, który został już opublikowany, ten, który zakwalifikowano do druku, a także ten, który - będąc przeznaczonym przez autora lub autorów do druku - nie został zakwalifikowany do publikacji. Znamię „tekst opublikowany” może być rozumiane jako tekst, który dane czasopismo opublikowało, lub jako tekst, który został opublikowany wcześniej, a czasopismo, korzystając z uprawnień przyznanych prasie przez prawo autorskie, przedrukowuje go (tzw. użytek publiczny na rzecz prasy - art. 25 prawa autorskiego). W praktyce często

${ }^{1}$ Ustawa z dnia 26 stycznia 1984 r. - Prawo prasowe, Dz.U. 1984, nr 5, poz. 24 ze zm.

2 Wyrok SA w Gdańsku z dnia 2 czerwca 2010 r., I ACa 382/10, LEX nr 653710. 
pozostaje błędne kwalifikowanie materiału prasowego jako artykułu prasowego, który odnosi się do wypowiedzi drukowanej.

Ustawa prasowa, jak również żaden inny akt prawny, nie definiuje wprost przestępstwa prasowego. Nie zawiera także terminu „przestępstwo prasowe”, a tylko określenia „przestępstwo, o którym mowa w art. 45-49a pr.pras.” oraz ,przestępstwo popełnione przez opublikowanie materiału prasowego", czyli przestępstwo popełnione w prasie (art. 37a pr.pras.). Powyższy stan powoduje, że mogą się pojawić trudności z precyzyjnym odszyfrowaniem enigmatycznych zapisów ustawodawcy w tym zakresie. Wydaje się, że próba odpowiedzi na pytanie, jak definiować przestępstwo prasowe, powinna być dwustopniowa. Przede wszystkim przestępstwo prasowe musi posiadać strukturę przewidzianą dla każdego przestępstwa, bez względu na to, jaki obszar zachowań ludzkich jest nim penalizowany. Będzie to zatem zachowanie człowieka, które przybierze postać czynu:

1) naruszającego normę sankcjonowaną;

2) bezprawnego, przy stwierdzeniu braku okoliczności wyłączających taki jego charakter;

3) karalnego, przy stwierdzeniu braku okoliczności wyłączających taki jego charakter;

4) karygodnego, czyli wykazującego wyższy niż znikomy stopień społecznej szkodliwości;

5) zawinionego, czyli podjętego w warunkach, w których od człowieka zdolnego do przypisania mu winy (poczytalnego i dojrzałego) można wymagać zachowania się zgodnego z nakazem lub zakazem prawa.

Jak wynika z powyższego, odpowiedzialność za popełnienie przestępstwa prasowego ukształtowana jest według zasad ogólnych przewidzianych w Kodeksie karnym. Wymienione przesłanki odpowiedzialności karnej muszą zostać spełnione kumulatywnie, tzn. na zasadzie koniunkcji. Zasadniczo można sobie wyobrazić popełnienie w działalności dziennikarza większości przestępstw powszechnych, zatem przejście do kategorii przestępstw określanych mianem prasowych powinno zostać poprzedzone odwołaniem się również do bliższych cech specyfikujących ten rodzaj inkryminowanej aktywności.

Mając na uwadze powyższe, należy stanąć na stanowisku, że przestępstwem prasowym jest zawiniony czyn bezprawny, którego społeczna szkodliwość jest wyższa niż znikoma, naruszający normy regulujące prawidłowe funkcjonowanie prasy, zapobiegające wykorzystywaniu jej do celów sprzecznych z prawem oraz zapewniające jej wolność. 


\section{Odpowiedzialność za przestępstwa prasowe - zarys historyczny}

Szczególny rodzaj odpowiedzialności, o którym mowa, przypisywany był instytucji zwanej redaktorem odpowiedzialnym. Wydany przez Naczelnika Państwa w dniu 7 lutego 1919 r. dekret w przedmiocie tymczasowych przepisów prasowych ${ }^{3} \mathrm{w}$ art. 16 nakładał na redaktora obowiązek złożenia deklaracji, iż weźmie na siebie kierowanie czasopismem w całości lub w części. Zapis ten, chociaż wprost tego nie artykułował, w swej istocie ustanawiał redaktora odpowiedzialnego. E. Czarny-Drożdżejko uważa, że w doktrynie i orzecznictwie nie było wątpliwości, że taka osoba ponosiła odpowiedzialność za przestępstwa prasowe ${ }^{4}$. Obowiązujące przez niespełna 3 lata Rozporządzenie Prezydenta Rzeczypospolitej z dnia 10 maja 1927 r. o prawie prasowym ${ }^{5}$ wymieniało expressis verbis redaktora odpowiedzialnego, który zgodnie z art. 20 musiał być wskazany na każdym egzemplarzu czasopisma. Ponosił on odpowiedzialność za treść czasopisma oraz za niedopełnienie innych obowiązków wynikających z przepisów rozporządzenia. Jeżeli ustanowiono kilku redaktorów odpowiedzialnych, wszyscy powinni byli być wymienieni wraz ze wskazaniem działu, za który każdy z nich odpowiadał. Jeżeli działu w ten sposób nie wymieniono, każdy $\mathrm{z}$ redaktorów odpowiedzialnych odpowiadał za treść całego czasopisma. Zgodnie z art. 22 rozporządzenia redaktorem odpowiedzialnym nie mógł być poseł na Sejm Rzeczypospolitej, członek Senatu Rzeczypospolitej oraz poseł na Sejm Śląski.

Poważnym problemem okresu 20-lecia międzywojennego był fakt, że odpowiedzialność za przestępstwo popełnione w treści materiału prasowego często ponosiła osoba, która w ogóle nie miała wpływu na treść publikacji. Działo się tak dlatego, że powszechnie ustanawiano w roli redaktorów odpowiedzialnych osoby fikcyjne, niemające $\mathrm{w}$ istocie żadnego wpływu na pracę redakcji ani treść przygotowywanych i publikowanych materiałów. Osoby takie nazywano „redaktorami do odsiadek”, a to z tego względu, że w przypadku przegranego przez gazetę procesu musieli ponieść tego konsekwencje łącznie $\mathrm{z}$ ewentualnym odbyciem kary pozbawienia wolności. Zatem jedyną kwalifikacją zawodową, jaką powinni byli się wykazać, była wytrzymałość na niedogodności płynące z przebywania w warunkach więziennych. Tak skrajnie formalne podejście do funkcji redaktora odpowiedzialnego było wysoce niemoralne i szkodli-

${ }_{3}^{3}$ Dekret Naczelnika Państwa z dnia 7 lutego 1919 r. w przedmiocie tymczasowych przepisów prasowych, Dz.U. 1919, nr 14, poz. 186 ze zm.

4 E. Czarny-DrożdżejKo: Przestępstwa prasowe. Warszawa 2013, s. 143.

${ }^{5}$ Rozporządzenie Prezydenta Rzeczpospolitej z dnia 10 maja 1927 r. o prawie prasowym, Dz.U. 1928, nr 1, poz. 1 ze zm. 
we dla ładu społecznego i poszanowania prawa ${ }^{6}$. W dekrecie Prezydenta Rzeczypospolitej z dnia 21 listopada 1938 r. Prawo prasowe zdecydowanie zerwano $\mathrm{z}$ dotychczasowym systemem redaktora odpowiedzialnego, gdyż w art. 16 zapisano, że jako redaktora można ustanowić tylko tego, kto ma prawo rozstrzygać o treści całego czasopisma lub działu, który ma redagować. Kształt regulacji wyraźnie dążył do materialnego pojmowania redaktora jako osoby mającej faktyczny wpływ na to, co się w redakcji dzieje i jakie materiały prasowe będą udostępniane czytelnikowi.

\section{Prawo anonimatu}

Wraz z rozwojem ustawodawstwa prasowego zaczęto poszukiwać alternatywnych rozwiązań w celu określenia kręgu podmiotów odpowiedzialnych za przestępstwa popełniane w treści materiałów ukazujących się na łamach prasy, tak aby zapewnić pokrzywdzonym skuteczną ochronę. Przyczyną takiego stanu rzeczy było ukształtowanie się prawa anonimatu pozwalającego na zachowanie $\mathrm{w}$ tajemnicy danych umożliwiających identyfikację autora materiału prasowego. Skorzystanie z anonimatu uniemożliwia uzyskanie danych osobowych „utajnionego” dziennikarza celem pociągnięcia go do odpowiedzialności ${ }^{7}$. $Z$ drugiej strony prawodawca dążył do zapewnienia rzetelnego wykonywania funkcji przez redaktorów, w tym redaktorów naczelnych dzienników i czasopism. Redaktorzy bowiem powinni przede wszystkim czuwać nad tym, aby inne osoby nie wykorzystywały prasy jako miejsca do popełniania przestępstw przy użyciu słowa. Powyższe przyczyny legły u podstaw ukształtowania w sposób odrębny odpowiedzialności karnej redaktora (redaktora naczelnego).

Zgodnie z art. 15 ust. 1 pr.pras. autor materiału prasowego decyduje o tym, jak będzie podpisany materiał jego autorstwa. Dziennikarz może go podpisać imieniem i nazwiskiem, pseudonimem lub udostępnić anonimowo. Jeśli autor materiału chce pozostać anonimowy, to żadna osoba nie może wyjawić jego imienia i nazwiska, pod groźbą odpowiedzialności karnej. Dotyczy to także osób wykonujących czynności usługowo-techniczne w redakcjach. Podpisanie przez dziennikarza materiału prasowego pseudonimem lub inicjałami swojego imienia i nazwiska bądź oświadczenie, że należy rozpowszechniać ten artykuł anonimowo, jest bezwzględnie wiążące dla redaktora naczelnego i wydawcy. Prawo do zachowania $\mathrm{w}$ tajemnicy swojego nazwiska przysługuje nie tylko dziennikarzowi, lecz także każdej osobie, która jest autorem materiału prasowego. Nie ma tu

6 T. Cyprian: Prawo prasowe. Poznań 1939, s. 18.

7 Wyrok WSA w Warszawie z dnia 13 lutego 2009 r., II SA/Wa 1570/08, LEX nr 519829. 
również znaczenia fakt, czy dany materiał został zakwalifikowany do publikacji, czy też nie. Przyznanie autorowi materiału prasowego prawa do zachowania $\mathrm{w}$ tajemnicy swego nazwiska rodzi po stronie dziennikarzy, zwłaszcza redaktorów i redaktorów naczelnych, obowiązek chronienia anonimowości takiej osoby, nieujawniania jej nazwiska ${ }^{8}$. W przypadku, gdy w materiale prasowym dziennikarza posługującego się pseudonimem doszło do naruszenia dóbr osobistych osoby trzeciej, pojawia się problem dotyczący podmiotu, który można pociągnąć do odpowiedzialności zarówno cywilnej, jak i karnej. W procesie cywilnym pozwanym może być osoba fizyczna, osoba prawna lub jednostka organizacyjna nieposiadająca osobowości prawnej. Pokrzywdzony może zatem pozwać redaktora naczelnego lub każdą inną osobę, która decydowała o upublicznieniu konkretnego materiału. Może zostać również pozwany wydawca, gdyż zgodnie z dyspozycją art. 38 pr.pras. odpowiedzialność cywilna redaktora naczelnego nie wyłącza odpowiedzialności wydawcy. Problem pojawia się w przypadku skorzystania przez pokrzywdzonego ze ścieżki procesu karnego, gdzie oskarżyć można tylko osobę fizyczną. Wydaje się, że w takim wypadku odpowiedzialność karna redaktora lub redaktora naczelnego (w zależności od tego, kto decydował o opublikowaniu materiału prasowego) opierać się będzie na podstawie art. 49a pr.pras. Zgodnie z cytowanym przepisem redaktor (redaktor naczelny), który nieumyślnie dopuścił do opublikowania materiału prasowego zawierającego znamiona przestępstwa, o którym mowa w art. 37a, ponosi za ten czyn odpowiedzialność karną.

\section{Redaktor naczelny - zadania i kompetencje}

Obecnie obowiązująca ustawa z dnia 26 stycznia 1984 r. Prawo prasowe wprowadza do przestrzeni prawnej dwie odrębne definicje legalne - redaktora oraz redaktora naczelnego. Zgodnie $\mathrm{z}$ art. 7 ust. 2 pkt 6 redaktorem jest dziennikarz decydujący lub współdecydujący o publikacji materiałów prasowych. Zatem jest to osoba, która ma rzeczywisty wpływ na zawartość merytoryczną dziennika lub czasopisma. W praktyce chodzi tutaj o redaktora wydania, czyli osobę decydującą o zawartości określonego numeru, a także dziennikarza pełniącego funkcję szefa działu oraz kierującego kształtem dodatku regionalnego danego periodyku. Należy zgodzić się z E. Ferenc-Szydełko, że termin „współdecydujący” może rodzić wątpliwości co do granicy odpowiedzialności za opublikowane tre-

\footnotetext{
${ }^{8}$ Wyrok WSA w Warszawie z dnia 13 lutego 2009 r., II SA/Wa 1570/08, LEX nr 519829.
} 
ści materiałów prasowych, gdyż jego stopień bywa trudny do ustalenia9 . Punkt 7 cytowanego przepisu statuuje definicję redaktora naczelnego, którym jest osoba posiadająca uprawnienia do decydowania o całokształcie działalności redakcji. Każdy redaktor naczelny jest równocześnie redaktorem, ale nie odwrotnie, gdyż niektóre przepisy ustawy adresowane są wyłącznie do redaktora naczelnego ${ }^{10}$. Konkretyzacja obowiązków redaktora naczelnego oraz wymogów, jakie powinien spełniać, znajduje się w art. 25 pr.pras. Funkcji redaktora naczelnego nie może pełnić ciało kolegialne, co wynika wprost z gramatycznej wykładni przepisu. Zastosowanie liczby pojedynczej czyni sytuację klarowną w przypadku ustalania podmiotu mogącego ponosić odpowiedzialność prawną. Analizowany zapis art. 7 ust. 2 pkt 7 pr.pras. przekonuje, że obecnie zerwano z ,fikcyjnym” redaktorem naczelnym, a to dlatego, że kierując redakcją, posiada on szereg uprawnień kierowniczych w stosunku do innych osób, począwszy od swoich zastępców, a skończywszy na personelu administracyjno-technicznym. Redaktor naczelny kreuje linię programową, podejmuje decyzje personalne, wskazuje potrzebę zajęcia się określonymi tematami, a nawet może zablokować ukazanie się każdego materiału prasowego. Jak wynika z powyższego, obecnie mamy do czynienia z materialną definicją redaktora naczelnego. $€$. Syldatk twierdzi, że redaktorem naczelnym nie jest osoba, która faktycznie kieruje działalnością redakcji, ale taka, która posiada takie kompetencje, choćby czasowo ich nie wykonywała. Ustawodawca bowiem kładzie nacisk na „posiadanie uprawnień”, a nie na ich faktyczne wykonywanie $^{11}$. W świetle odpowiedzialności za przestępstwo prasowe istotne jest ustalenie momentu, od którego określona osoba może być uznana za redaktora naczelnego. Odpowiedź na to pytanie rozpocząć należy od przypomnienia, że obowiązujący w naszym kraju system rejestracyjny odnosi się tylko do dzienników i czasopism, gdzie należy wyróżnić trzy momenty, od których określoną osobę można uznać za redaktora naczelnego:

1) faktyczne wypełnianie takich obowiązków;

2) wpis do rejestru dzienników i czasopism;

3) prawomocność postanowienia o dokonaniu wpisu do rejestru.

Łatwo można zauważyć, że różnice czasowe pomiędzy wymienionymi zdarzeniami mogą być znaczne. W przypadku innych form prasy, poza dziennikami i czasopismami, wątpliwości nie ma, gdyż redaktorem naczelnym staje się osoba, której wręczono akt powołania, oznaczający faktyczne wykonywanie tej funkcji. Mając powyższe na uwadze, nale-

9 E. Ferenc-Szydetko: Prawo prasowe. Komentarz. Warszawa 2010, s. 84.

10 J. Sobczak: Prawo prasowe. Komentarz. Warszawa 2008, s. 340.

11 Ł. SyldatK: Komentarz do art. 7 Prawa prasowego. W: Prawo prasowe. Komentarz. Red. B. Kosmus, G. KuczyŃski. Warszawa 2011, s. 131. 
ży podzielić te poglądy doktryny, które opowiadają się za tym, żeby za redaktora naczelnego uznać osobę, która faktycznie została powołana przez wydawcę lub inny uprawniony organ na to stanowisko ${ }^{12}$. Trzeba również odnotować istnienie stanowiska odmiennego, zaprezentowanego przez Naczelny Sąd Administracyjny, według którego dana osoba staje się redaktorem naczelnym $\mathrm{z}$ chwilą uprawomocnienia się postanowienia o dokonaniu wpisu ${ }^{13}$. Przyjęcie takiego stanowiska prowadziłoby do opowiedzenia się za koncepcją mieszaną, formalno-materialną redaktora naczelnego. Należy ją odrzucić z uwagi na ochronę praw osób trzecich, które moga paść ofiarą przestępstwa popełnionego w treści materiału prasowego. Można bowiem sobie wyobrazić sytuację, w której osoba wykonująca faktycznie obowiązki redaktora naczelnego i mająca wpływ na publikację będzie próbowała uchylić się od odpowiedzialności karnej, powołując się na nieprawomocność wpisu do rejestru.

\section{Odpowiedzialność karna wynikająca $z$ art. 49a ustawy Prawo prasowe}

Stosownie do brzmienia art. 49a pr.pras. redaktor, który nieumyślnie dopuścił do opublikowania materiału prasowego zawierającego znamiona przestępstwa, o którym mowa w art. 37a, podlega grzywnie albo karze ograniczenia wolności. Przyznać należy, że komentowany przepis z punktu widzenia zasad prawidłowej legislacji brzmi dość kuriozalnie, albowiem dla jego rekonstrukcji konieczne jest zapoznanie się z treścią art. 37a. Pomimo tego dalej nie można dokonać pełnej charakterystyki przestępstw, o jakie ustawodawcy chodziło, gdyż artykuł ten w sposób dorozumiany odsyła do innych przepisów. Sąd Najwyższy w uchwale z dnia 28 października 1993 r., I KZP 22/9314, wskazał, iż przestępstwem, o którym mowa w art. 37a, jest nie tylko taki czyn przestępny, do którego znamion ustawowych należy działanie poprzez opublikowanie materiału prasowego i jest ono wymienione expressis verbis, lecz również inny czyn przestępny, jeżeli jego znamiona zostały zawarte w treści opublikowanego materiału prasowego. Dalej zostało podkreślone, iż użyty przez ustawodawcę w treści tegoż artykułu zwrot „przestępstwo popełnione przez opublikowanie materiału prasowego" należy rozumieć jako czyny przestępne, których sprawca dopuścił się przez opublikowanie materiału prasowego

12 M. Zaremba: Prawo prasowe. Ujęcie praktyczne. Warszawa 2007, s. 33.

13 Postanowienie NSA z dnia 21 stycznia 1997 r., II SA/Kr 1677/96, niepublikowane, cyt. za: E. Czarny-DrożdżejKo. W: Prawo mediów. Red. J. Barta. Warszawa 2008, s. 725.

${ }^{14}$ Uchwała SN z dnia 28 października 1993 r., I KZP 22/93, OSNKW 1993, nr 11-12, poz. 70 . 
zawierającego treść naruszającą przepisy prawa karnego. Przestępstwem takim może więc być zarówno czyn, którego znamieniem ustawowym jest opublikowanie materiału prasowego, jak również może nim być każde inne przestępstwo, które zostało popełnione w taki właśnie sposób, jakkolwiek taki sposób działania nie należy do znamion ustawowych tego przestępstwa. W praktyce problematyka odpowiedzialności prawnej w związku z publikacjami materiałów prasowych (art. 37 pr.pras.) będzie przedmiotem analizy głównie przy odpowiedzialności cywilnej za naruszenie dóbr osobistych oraz w zakresie odpowiedzialności karnej za przestępstwa prywatnoskargowe przeciwko czci. W tym kontekście warto pamiętać, iż w świetle Prawa prasowego materiałem prasowym są również listy do redakcji, o ile zostały do niej przesłane w celu ich opublikowania. Zamieszczenie takiego listu nie stanowi cytowania cudzej wypowiedzi, a zatem nie zwalnia redaktora naczelnego z odpowiedzialności ${ }^{15}$. Rekonstrukcja normy karnej nawet $\mathrm{w}$ wypadku zapoznania się $\mathrm{z}$ przepisem art. 37 a pr.pras. nie pozwala na konkretne wskazanie znamion przestępstw objętych zakresem normowania art. 49a, stąd też konieczne jest sięgnięcie do innych przepisów, do których w sposób dorozumiany odsyła art. 37a. Wydaje się, iż należy podzielić zdanie podniesione w literaturze, zgodnie z którym ustawodawca chciał określić, kto ponosi odpowiedzialność za przestępstwo popełnione przez opublikowanie materiału prasowego $^{16}$.

Pomimo jednak braku precyzji legislacyjnej zabieg odkodowania treści art. 49a pr.pras. jest możliwy do przeprowadzenia. Należy zatem stwierdzić, że w myśl cytowanego przepisu odpowiedzialność karną ponosi redaktor, który nieumyślnie dopuścił do opublikowania materiału prasowego, jeśli materiał ten zawiera znamiona jakiegokolwiek przestępstwa. Przykładowo można podać, że chodzi tutaj o takie przestępstwa, jak: zniesławienie, zniewaga, ujawnienie tajemnicy śledztwa bądź tajemnicy dziennikarskiej, rozpowszechnianie materiału prasowego objętego przepadkiem, naruszenie zasad autoryzacji czy wadliwa publikacja impressum. Czyn zabroniony $\mathrm{z}$ art. 49a ma charakter indywidualny, gdyż może go popełnić tylko redaktor, w tym redaktor naczelny. Wystarczy, iż zaniedba on swoje obowiązki w ten sposób, że dopuści do publikacji bezprawny materiał prasowy. Z powyższego jednoznacznie wyłania się rola, jaką pełni omawiany przepis w porządku prasowo-wydawniczym. Ustawodawca chciał zmusić redaktorów do dbałości, by nie pozwalali in-

15 Wyrok SN z dnia 28 września 2000 r., V KKN 171/98, OSNKW 2001, nr 3-4, poz. 31.

${ }^{16}$ Prawo mediów... 
nym osobom na popełnianie umyślnych czynów kryminalnie bezprawnych na łamach prasy.

W ramach analizy odpowiedzialności redaktora za przestępstwa prasowe nie można nie zauważyć art. 25 ust. 4a pr.pras., w którym ustawodawca wskazał na możliwe zaistnienie takich stanów faktycznych, które doprowadzą do uzyskania przez redaktora naczelnego immunitetu procesowego. $Z$ treści tego przepisu wynika, iż w takim przypadku odpowiedzialność karną poniesie wskazany przez niego redaktor (tzw. redaktor odpowiedzialny). Przykładem okoliczności, w których mamy do czynienia z immunitetem procesowym, jest uzyskanie mandatu posła lub senatora czy pełnienie funkcji sędziego. Instytucja ta bowiem nie stanowi o wyłączeniu przestępności lub karalności czynu, a zatem nie wywołuje skutków na gruncie prawa karnego materialnego. Oznacza natomiast, że $\mathrm{w}$ przypadku popełnienia przestępstwa przez określone osoby nie można wszcząć i prowadzić postępowania karnego ${ }^{17}$. Z treścią wskazanego przepisu koresponduje Rozporządzenie Ministra Sprawiedliwości z dnia 9 lipca 1990 r. ${ }^{18}$ w sprawie rejestru dzienników i czasopism, wydane na podstawie art. 23a pr.pras. Zgodnie z tym aktem prawnym księga rejestrowa powinna zawierać m.in. dane redaktora naczelnego oraz redaktora odpowiadającego na podstawie art. 49a (rubryka czwarta księgi). Organ rejestracyjny nie został jednak wyposażony w kompetencję do odmowy rejestracji w sytuacji, gdy wniosek o rejestrację nie zawiera danych redaktora wskazanego $\mathrm{w}$ art. 49 a. Zgodnie bowiem $\mathrm{z}$ art. 21 pr.pras. przyczyny uzasadniające decyzję odmowną zostały enumeratywnie wyliczone.

Omawiane przestępstwo można popełnić tylko nieumyślnie, w obu postaciach nieumyślności. Umyślne dopuszczenie przez redaktora do ukazania się bezprawnego materiału prasowego nie stanowi czynu z art. 49a pr.pras., ale współsprawstwo przestępstwa umyślnego innego typu. Dzięki konstrukcji przyjętej $\mathrm{w}$ art. 49a pr.pras. będzie możliwe przypisanie odpowiedzialności za dopuszczenie do opublikowania materiału prasowego $\mathrm{w}$ sytuacji, gdy przepis szczególny, zawierający znamiona danego przestępstwa prasowego, wymaga po stronie podmiotowej przestępstwa umyślności. Taka sytuacja może dotyczyć ujawnienia w prasie bez zezwolenia informacji z postępowania przygotowawczego. Jeżeli redaktor nie miał świadomości co do statusu ujawnianych informacji, a mimo to dopuścił do ich opublikowania, to niemożliwe byłoby przypisanie mu odpowiedzialności na podstawie art. $241 \S 1$ k.k., który to przepis statuuje przestępstwo o charakterze umyślnym. Wówczas, jeżeli udałoby się wyka-

17 Prawo karne materialne. Część ogólna. Wyd. 3. Red. M. Mozgawa. Warszawa 2011, str. 129.

18 Dz.U. 1990, nr 46, poz. 275. 
zać, że redaktor nie dochował należytej staranności i przez to nie ustalił, że ma do czynienia z tajemnicą śledztwa, możliwe byłoby przypisanie mu odpowiedzialności karnej za przestępstwo z art. 49a. Opisywany występek redaktor może popełnić, chociażby sprawca „czynu głównego” z jakichkolwiek powodów nie ponosił odpowiedzialności karnej. Wprawdzie do znamion czynu z art. 49a pr.pras. należy wyłącznie dopuszczenie do cudzego bezprawnego działania, niezależnie od stopnia jego społecznej szkodliwości, jednak także w odniesieniu do sprawcy czynu z art. 49a pr.pras. należy przykładać miernik szkodliwości społecznej. Znikomość szkodliwości czynu głównego z reguły spowoduje znikomość szkodliwości zachowania redaktora, a w konsekwencji jego bezkarnośćc ${ }^{19}$. Do znamion omawianego przestępstwa nie należy wywołanie jakichkolwiek dodatkowych skutków (przestępstwo formalne). Karnemu wartościowaniu podlega nie tylko dopuszczenie do ukazania bezprawnych materiałów redakcyjnych, ale także sprostowań, odpowiedzi, reklam, ogłoszeń, listów do redakcji, polemik ${ }^{20}$. Analizując zachowania zakodowane w art. 49a pr.pras., nie można pominąć regulacji wynikającej z art. 116 Kodeksu karnego, wedle której do przestępstw prasowych mają odpowiednie zastosowanie przepisy części ogólnej tego aktu prawnego. Oznacza to, że jeżeli ustawa Prawo prasowe nie przewiduje w tym zakresie szczególnych regulacji, w kwestii odpowiedzialności karnej redaktora znajdą zastosowanie wszystkie reguły części ogólnej Kodeksu karnego.

Redaktor, który nieumyślnie dopuścił do opublikowania materiału prasowego zawierającego znamiona przestępstwa, o którym mowa $\mathrm{w}$ art. 37a pr.pras., podlega grzywnie albo karze ograniczenia wolności. Zarówno grzywna, jak i kara ograniczenia wolności wymierzane są w trybie i na zasadach określonych w Kodeksie karnym. Niewątpliwie wskazane zagrożenie pokazuje ewolucję polskiego prawa prasowego na przestrzeni ostatnich trzydziestu lat w kierunku ograniczania jego restryktywności. Kierunek taki uznać należy za prawidłowy, gdyż nadmierna penalizacja stosunków prasowych oraz wydawniczych jest nie do przyjęcia w demokratycznym państwie prawnym.

Ustawodawca w art. 53 ust. 2 pr.pras. przyznał Ministrowi Sprawiedliwości kompetencję do wydania przepisów wykonawczych dotyczących wyznaczenia sądów rejonowych właściwych do rozpoznawania spraw o przestępstwa, o których mowa w art. 47-49a oraz o przestępstwa popełnione w prasie na obszarze właściwości danego sądu okręgowego. Realizując delegację ustawową w dniu 8 lipca 2014 r., Minister Sprawiedliwości wydał

19 Prawo prasowe. Komentarz. Red. B. Kosmus..., s. 590.

${ }^{20}$ Uchwała SN z dnia 28 października 1993 r., I KZP 22/93, OSNKW 1993, nr 11-12, poz. 70 . 
aktualnie obowiązujące rozporządzenie ${ }^{21}$. W art. 53 ust. 3 ustawodawca wprowadził normę przemienną w zakresie właściwości miejscowej spraw o przestępstwa prasowe. Norma ta oparta została na systemie gradacji, który modyfikuje przepisy ogólne dotyczące właściwości miejscowej uregulowane w Kodeksie postępowania karnego. Właściwość miejscową ustala się zatem w pierwszej kolejności według siedziby redakcji. Jeżeli przykładowo redakcja ma swoją siedzibę we Wrocławiu, a pokrzywdzony artykułem mieszka w Białej Podlaskiej, sądem właściwym do rozpoznania sprawy będzie Sąd Rejonowy dla Wrocławia-Śródmieścia. Jeżeli siedziba redakcji nie jest znana, rozpoznanie sprawy będzie należeć do sądu właściwego dla siedziby wydawnictwa. Z kolei, jeżeli siedziba wydawnictwa nie jest znana lub znajduje się poza granicami kraju, wówczas sprawa będzie należeć do kompetencji miejscowej sądu właściwego dla miejsca popełnienia czynu (ujawnienia i rozpowszechniania materiału prasowego). W sytuacji natomiast, gdy w tej samej sprawie wszczęto postępowanie $\mathrm{w}$ kilku sądach, zgodnie $\mathrm{z}$ omawianą normą kolizyjną właściwy będzie sąd, w którym najpierw wszczęto postępowanie.

Podsumowując, należy podkreślić, iż art. 49a pr.pras. nie stanowi przykładu przepisu zredagowanego zgodnie z zasadami poprawnej legislacji. Pod adresem omawianego artykułu można wskazać wiele zarzutów, np. brak dostatecznej określoności czy „piętrowe” odesłania. Nie sposób jednak pominąć faktu, iż obecnie w systemie prawnym nie ma innego alternatywnego przepisu. Nadto dość niefortunna projekcja art. 49a pr.pras. w sposób znaczący utrudnia, ale nie uniemożliwia rekonstrukcji normy karnej.

\section{Bibliografia}

\section{Literatura}

CYPRIAN T.: Prawo prasowe. Poznań 1939.

CZARnY-DrożdżejKo E.: Przestępstwa prasowe. Warszawa 2013.

Ferenc-SzydeŁKo E.: Prawo prasowe. Komentarz. Warszawa 2010.

Prawo karne materialne. Część ogólna. Wyd. 3. Red. M. Mozgawa. Warszawa 2011. Prawo mediów. Red J. BarTa. Warszawa 2005.

SobczaK J.: Prawo prasowe. Komentarz. Warszawa 2008.

SYlDATK Ł.: Komentarz do art. 7 Prawa prasowego. W: Prawo prasowe. Komentarz.

Red. B. Kosmus, G. KuczyńsKi. Warszawa 2011.

Zaremba M.: Prawo prasowe. Ujęcie praktyczne. Warszawa 2007.

${ }^{21}$ Rozporządzenie Ministra Sprawiedliwości z dnia 8 lipca 2014 r. w sprawie wyznaczenia sądów rejonowych rozpoznających sprawy o przestępstwa prasowe, Dz.U. 2014, poz. 966. 
Orzecznictwo

Uchwała SN z dnia 28 października 1993 r., I KZP 22/93. OSNKW 1993, nr 1112, poz. 70 .

Wyrok SN z dnia 28 września 2000 r., V KKN 171/98. OSNKW 2001, nr 3-4, poz. 31.

Postanowienie NSA z dnia 21 stycznia 1997 r., II SA/Kr 1677/96.

Wyrok WSA w Warszawie z dnia 13 lutego 2009 r., II SA/Wa 1570/08. LEX nr 519829.

Wyrok SA w Gdańsku z dnia 2 czerwca 2010 r., I ACa 382/10. LEX nr 653710. 